Review

\title{
Serenoa Repens (Saw Palmetto) for Lower Urinary Tract Symptoms (LUTS): The Evidence for Efficacy and Safety of Lipidosterolic Extracts. Part II
}

\author{
Stephen B. Strum $\mathbb{1}$
}

check for updates

Citation: Strum, S.B. Serenoa Repens (Saw Palmetto) for Lower Urinary Tract Symptoms (LUTS): The Evidence for Efficacy and Safety of Lipidosterolic Extracts. Part II. Uro 2021, 1, 139-154. https://doi.org/ 10.3390 /uro1030016

Academic Editor: Mauro Gacci

Received: 2 July 2021

Accepted: 27 July 2021

Published: 2 August 2021

Publisher's Note: MDPI stays neutral with regard to jurisdictional claims in published maps and institutional affiliations.

Copyright: (C) 2021 by the author. Licensee MDPI, Basel, Switzerland. This article is an open access article distributed under the terms and conditions of the Creative Commons Attribution (CC BY) license (https:// creativecommons.org/licenses/by/ $4.0 /)$.
Community Practice of Hematology, Oncology and Internal Medicine, Focus on Prostate Cancer and Prostate Diseases, Nevada City, CA 95959, USA; sbstrum@gmail.com

\begin{abstract}
Part I of this 3-part series provided the groundwork for understanding the role of a standardized lipidosterolic extract of Serenoa repens (LSESr) in the treatment of LUTS. It documented that a treatment having a high therapeutic index (i.e., a ratio of benefit to adverse reactions) is a critical need in the demographic context of a rapidly growing elder population. Part I described the clinical symptomatology of LUTS and how it is quantified. A critique of the reports from four authoritative bodies: the European Scientific Cooperative on Phytotherapy (ESCOP), Cochrane 2012, the European Medicines Agency (EMA), and the AUA (American Urological Association) was presented. The foundation above then fine-tuned our search to require (a) consistent evaluability criteria, (b) the quantification of clinical findings, (c) the need to focus on studies employing a standardized LSESr product meeting the fatty acid profile set forth by the European Medicines Agency (EMA) and the US Pharmacopeia and (d) a global assessment of scientific investigations published in all languages and not limited to only English. With the above four constraints, "new" findings about LSESr vs. LUTS are presented. How did the search strategy and selection criteria lead to new understandings about the role of LSESr vs. LUTS? How safe is LSESr in contrast to its counterpart prescription drugs? Of the proposed major mechanisms of action of LSESr (e.g., 5-alpha reductase inhibition and anti-inflammatory activity), what are the key points? After initiating treatment with LSESr, when is clinical improvement seen? How durable is LSESr in ameliorating LUTS? Can LSESr prevent the progression of $\mathrm{BPH}$ ?
\end{abstract}

Keywords: lower urinary tract symptoms; LUTS; benign prostatic hyperplasia; BPH; saw palmetto; Serenoa repens; phytotherapy; lipidosterolic extract of Serenoa repens (LSESr); hexanic extract of Serenoa repens (HESr); ethanolic extract of Serenoa repens (EESr); hypercritical $\mathrm{CO}_{2}$ extract of Serenoa repens (hCESr); supercritical carbon dioxide extraction of Serenoa repens (sCESr)

\section{Search Strategy and Selection Criteria Were Pivotal to Perspective on LSESr vs. LUTS}

At the beginning of this analysis of Serenoa repens in the treatment of LUTS it seemed most appropriate to first lay the groundwork and define the importance, the nature, and the vocabulary of LUTS, and then follow this with an analysis of the four key reviews (ESCOP 2003, Cochrane 2012, AUAG 2014 and EMA 2014) that have impacted the acceptability of Serenoa repens in LUTS treatment. It quickly became clear that a global review of the peerreviewed literature would be needed in light of the plethora of non-English publications, many of which had never been translated and referenced, and thus ignored in analyzing the efficacy of Serenoa repens in LUTS. Given how important the above modus operandi has been to fully appreciate the role of Serenoa repens in LUTS, and that such an approach would likely have relevance to other scientific investigations, the details concerning search strategy and selection criteria are presented below.

The initial approach to gain a general understanding of the therapeutic index of LSESr in the treatment of male LUTS involved a standard search of peer-reviewed literature 
using PubMed and Google Scholar with the main focus being on clinical research papers. Citations from within these retrieved papers were then used to identify additional relevant publications. We excluded from review any studies that included men with stage III/IV $\mathrm{BPH}$ because they are at high risk for acute urinary retention and not reasonable candidates for LSESr monotherapy. Such studies used the Alken or Vahlensieck staging classifications for BPH which urologists rarely use today [1-3]. Also important to note, in this 3-part review, papers dating back to 1983 were considered, and our exclusion criteria recognized both the merits and/or limitations of those two staging approaches. Case reports were also excluded.

In all, 1575 citations relating to LSESr were identified. Publications related to animal studies, pharmacologic investigations, or pathology findings were read, but were not considered relevant to the immediate focus on the clinical issues relating to LSESr vs. LUTS. Of the 1575 articles, 190 were considered relevant and therefore possibly eligible for inclusion, with 118 of these (62\%) not being English-language publications and requiring translation into English. Within those 190 eligible publications, there were differences in study design (open, comparative, blinded, placebo-controlled); dose (mg per day); dosing (once a day vs. twice a day); study duration; the active ingredient profile of the LSESr product, and the rigor of statistical analysis. Any of these factors could result in clinical results that could impact our understanding of the efficacy of LSESr vs. LUTS. Some studies involved small sample sizes and were of short duration. If the number of patients at the end of the study was less than twenty, that publication was arbitrarily excluded from this author's analysis. It was similarly decided that studies with durations of less than two months would also be considered non-evaluable to assess LSESr efficacy vs. LUTS. If the dose of LSESr was not stated, or the extraction method was not identified, or the LSESr product had not been previously verified as meeting EMA or USP standards for quality, then those studies were also excluded.

The selection of a minimum of 20 patients at the end of the study, and a study duration of at least two months was arbitrary. It was decided that a subset analysis of studies of less than 20 patients at the study end, or less than two months duration could be done to see if they altered the conclusions reached in this global review. Studies were also eliminated from analysis if other phytotherapeutic agents were given in combination with LSESr. Studies of LSESr involving patients with chronic prostatitis/chronic pelvic pain syndrome (CP/CPPS) Types I-IV were considered not evaluable for study. After the review of the selected papers was completed, it became evident that some of the arbitrary decisions (e.g., patient number and study duration) would not have impacted the conclusions reached in our analysis. As mentioned later in discussing the anti-inflammatory effect of LSESr, the cohort of patients with CP/CPPS Types III and IV would have been a reasonable subset for analysis given this important mechanism of action of LSESr. This may well be the subject of a future analysis. Sixty review articles or meta-analyses did not present original data on LSESr efficacy, or the lack thereof. The process for identifying evaluable studies and the reason for exclusion as non-evaluable are provided in Figure 1.

The retrieval of full-text articles was immeasurably enhanced by using either the PubMed ID (PMID) or Digital Object Identifier (DOI) information when using the services of the reprint desk at Oregon Health Sciences University (OHSU), and EurekaMag.com. These resources were a necessity in the retrieval of PDFs of many articles not available via PubMed, Google Scholar, or the journal in which the study was published. On several occasions, the corresponding author was emailed and asked to clarify items such as the extraction process or the dose of the LSESr product. More often than not, the author's responses to such emails were received. Some authors volunteered additional publications that had been missed by all of the above search techniques. This was especially the case regarding publications from Spain, Italy, and Russia.

Non-English-language articles were initially sent for formal translation into English, but due to the high expense of commercial translation services incurred after the first four such translations, this author successfully translated articles from German, Italian, 
Spanish, Chinese, Russian, Portuguese, and Slovak to English using Mac OS X apps such as Easy Translator 14 (www.acetools.net (accessed on 17 January 2019)) in association with an editing app called TextSoap version 8 (www.unmarked.com/textsoap/ (accessed on 17 September 2017)). The non-English text within graphics was similarly translated, and when images were modified and reproduced for this review, they were edited using a Mac OS X screen capture app called Voila (www.globaldelight.com (accessed on 30 June 2016)). These translated articles were saved as Word documents and exported to PDF format. Using this approach, a total of 118 non-English-language peer-reviewed publications were scrutinized. If it was apparent after the initial translation of the first few pages that the publication was not relevant to this project, then a full translation to English was aborted. Of the 118 non-English-language articles, 83 (70\%) appeared evaluable, and they were fully translated to English.

1575 Citations and Contributed Papers Considered for Eligibility (includes additional citations identified from publication reference list and non-English-language papers contributed to this review by corresponding authors)

\begin{tabular}{|c|c|c|c|c|c|}
\hline & & & & & $\begin{array}{l}118 \text { non-English } \\
\text { articles translated }\end{array}$ \\
\hline & & (Engl & $\begin{array}{r}190 \text { Eligil } \\
\text { ish and non- }\end{array}$ & $\begin{array}{l}\text { ble Papers } \\
\text { English Language) }\end{array}$ & \\
\hline & & $\begin{array}{ll}\text { Eligibi } \\
\text { - } \geq 2 \\
\text { - } \geq 2 \\
\text { - Hui } \\
\text { - } \\
\text { - } \\
\text { - } \\
\text { - } \\
\text { - } \\
\text { - } \\
\text { - Ext } \\
\text { - } & \text { Inte } \\
\text { Int }\end{array}$ & $\begin{array}{l}\text { lity criteria: } \\
0 \text { patients } \\
\text { month durat } \\
\text { man study } \\
\text { ginal researc } \\
\text { notherapy } \\
\text { ndard dose (3 } \\
\text { nical evaluati } \\
\text { raction meth } \\
\text { rpretable dat }\end{array}$ & $\begin{array}{l}\text { ion } \\
\text { h } \\
\text { ion of LUTS/BPH } \\
\text { od/product known } \\
\text { ta }\end{array}$ & \\
\hline $\begin{array}{c}\text { Citation } \\
\text { Language }\end{array}$ & & luable & $\begin{array}{c}\text { Non- } \\
\text { Evaluable }\end{array}$ & Exclusion Ration & \\
\hline English & 31 & & 76 & Reviews/meta-ana & is (60 publications) \\
\hline German & 11 & & 16 & Study duration $(<$ & nonths; 11 studies) \\
\hline Russian & 6 & & 10 & Low patient numb & ( $<20$ patients; 13 studies $)$ \\
\hline Italian & 5 & & 17 & Not monotherapy & studies) \\
\hline French & 2 & & 10 & Non-standard dose & studies) \\
\hline Spanish & 1 & & 1 & Extraction/product & nknown (3 studies) \\
\hline Portuguese & 1 & & 0 & In vitro/lab (5 stud & ) \\
\hline Slovak & 1 & & 0 & Animal study (4 st & \\
\hline Chinese & 0 & & 2 & Other reasons (13 & dies) \\
\hline Total & 58 & & 132 & & \\
\hline
\end{tabular}

Figure 1. Disposition of 190 eligible papers. * Sixty evaluable studies (31\%) with one duplication. Since Robert 2015 [4] and Latil 2015 [5] were separate papers but reported the same data they were counted as one study. + May contain more than one reason for exclusion.

Most importantly, data extraction relating to changes in IPSS, QoL, and Qmax from the 107 English-language and 83 non-English-language eligible studies was performed. When such data were not provided in the text of the publication, data were obtained from graphics 
within the paper when possible. Specifically, when graphs were presented but no absolute numerical values were presented in the text, an estimation of the numerical values relating to IPSS, QoL, and Qmax was determined (SBS). After full translation and data extraction, 27 of the 83 non-English-language papers (32\%) met the criteria for evaluability. These non-English-language publications and basic information compiled from these studies are shown in Table 1.

Table 1. Evaluable non-English-language papers (27 studies) were categorized by the extraction method, the average number of patients, the study duration, and the clinical endpoints IPSS, QoL, and Qmax.

\begin{tabular}{|c|c|c|c|c|c|c|c|c|c|c|c|}
\hline \multirow{2}{*}{ First Author } & \multirow{2}{*}{$\begin{array}{c}\text { Ref } \\
\#\end{array}$} & \multirow{2}{*}{ Year } & \multirow{2}{*}{$\begin{array}{l}\text { Extraction } \\
\text { Method }\end{array}$} & \multirow{2}{*}{ Serenoa Patients (\#) a } & \multirow{2}{*}{$\begin{array}{c}\text { Study } \\
\text { Duration (mos) }\end{array}$} & \multicolumn{2}{|c|}{ IPSS } & \multicolumn{2}{|c|}{ QoL } & \multicolumn{2}{|c|}{ Qmax } \\
\hline & & & & & & $\Delta$ & $\%$ & $\Delta$ & $\%$ & $\Delta$ & $\%$ \\
\hline Cirillo-Marucco $\varepsilon$ & {$[6]$} & 1983 & Hexane & 47 & 4 & & 56 & & & +4.6 & 50 \\
\hline Cukier $\psi \lambda$ & [7] & 1985 & Hexane & 73 & 2 & & 33 & & & & \\
\hline Tosto $\Omega$ & [8] & 1985 & Hexane & 20 & 3 & -5.0 & 28 & & & & \\
\hline Pannunzio & [9] & 1986 & Hexane & 30 & 2 & & & & & +5.0 & 74 \\
\hline Pescatore & [10] & 1986 & Hexane & 30 & 3 & & & & & +2.5 & 27 \\
\hline Authie $\pi$ & [11] & 1987 & Hexane & 500 & 3 & & 78 & & & & \\
\hline Ollé Carreras $\varphi$ & [12] & 1987 & Hexane & 40 & 2 & & 68 & & & & \\
\hline Orfei $\chi$ & [13] & 1988 & Hexane & 30 & 3 & & 50 & -2.2 & & +0.0 & 0.2 \\
\hline Mattei $\psi \omega$ & [14] & 1990 & $\mathrm{CO}_{2}$ & 20 & 3 & & 55 & & & & \\
\hline Dathe & {$[15]$} & 1991 & Hexane & 49 & 6 & & & & & +5.9 & 49 \\
\hline Vahlensieck D & [16] & 1993 & $\mathrm{CO}_{2}$ & 1334 & 4 & & 47 & & & & \\
\hline Vahlensieck & {$[17]$} & 1993 & $\mathrm{CO}_{2}$ & 312 & 3 & & & & & +5.8 & 52 \\
\hline Fabricius $\delta$ & [18] & 1993 & $\mathrm{CO}_{2}$ & 176 & 6 & & $39 ; 59$ & & & & \\
\hline Derakhshani & [19] & 1997 & Ethanol & 1047 & 3 & -7.4 & 40 & -1.6 & 46 & +3.7 & 31 \\
\hline Eickenberg & [20] & 1997 & Ethanol $96 \%$ & 6967 & 6 & -8.0 & 44 & -1.8 & 38 & +3.0 & 23 \\
\hline Foroutan & {$[21]$} & 1997 & Hexane & 592 & 3 & -6.5 & 38 & -1.5 & 45 & +5.9 & 66 \\
\hline Redecker $v$ & {$[22]$} & 1998 & Ethanol $90 \%$ & 50 & 3 & & 48 & & & +3.4 & 24 \\
\hline Ziegler $\Theta$ & {$[23]$} & 1998 & Ethanol $90 \%$ & 109 & 3 & & & & 36 & +3.7 & 29 \\
\hline Bauer $\gamma \psi$ & {$[24]$} & 1999 & $\mathrm{CO}_{2}$ & 101 & 6 & & 37 & & & & 16 \\
\hline Medeiros $t$ & [25] & 2000 & Hexane & 130 & 3 & -6.5 & 37 & -1.4 & 39 & +2.0 & 22 \\
\hline Aliaev & [26] & 2002 & Hexane & 26 & 60 & -8.8 & 76 & -1.3 & 53 & +4.3 & 35 \\
\hline Breza & {$[27]$} & 2005 & Ethanol & 596 & 12 & -5.9 & 36 & -1.7 & 54 & +2.3 & 19 \\
\hline Aliaev & {$[28]$} & 2007 & Ethanol & 50 & 6 & -2.9 & 26 & -1.8 & 43 & +1.7 & 14 \\
\hline Razumov & [29] & 2007 & Ethanol & 30 & 6 & -6.9 & 43 & 2.7 & 68 & +2.8 & 23 \\
\hline Aliaev $\infty$ & {$[30]$} & 2009 & Ethanol & 50 & 24 & -4.2 & 37 & -2.2 & 52 & +2.7 & 21 \\
\hline Vinarov & [31] & 2010 & Ethanol & 50 & 36 & -6.0 & 50 & -2.0 & 50 & +4.5 & 39 \\
\hline Aliaev & [32] & 2013 & Ethanol & 38 & 120 & -1.3 & 12 & -1.1 & 35 & +3.3 & 26 \\
\hline Mean Across All 27 & tudies & & & 463 & 12 & -5.8 & $40-41^{b}$ & -1.8 & 47 & +3.5 & 31 \\
\hline $\begin{array}{l}\text { Hexane extraction } \\
\text { Ethanol extraction } \\
\text { Carbon dioxide ext }\end{array}$ & $\begin{array}{l}12 \\
10 \\
\text { tion } n\end{array}$ & & & & & & & & & & \\
\hline
\end{tabular}

Values for IPSS, QoL, and Qmax rounded off to one decimal point. Percentages rounded off to nearest whole number. ${ }^{\text {a }}$ number of patients at study end, or as reported. $\varepsilon$ Cirillo-Marucco study done prior to IPSS; raw data on nocturia. $\psi$ placebo-controlled studies. $\lambda$ Cukier study done prior to IPSS; raw data on nocturia. $\Omega$ Tosto study done prior to IPSS; authors used a unique point scoring to evaluate frequency, nocturia, incomplete emptying, weak stream. $\pi$ Authie done prior to IPSS use; nocturia, frequency, and urgency improvements were $82 \%$, $67 \%$, and $85.3 \%$, respectively (average improvement $78.1 \%$ ); average complete resolution of these symptoms was $43.5 \%$. $\varphi$ Ollé Carreras IPSS not used. The number shown is based on the changes in frequency with complete resolution in 27 out of 40 patients. $\chi$ Orfei used scores from frequency, nocturia, urgency, weak stream, and straining at study beginning vs. end. $\omega$ Mattei used scores from frequency, nocturia, and incomplete emptying. P Vahlensieck did not use IPSS. The data is based on the change in frequency and nocturia before and after LSESr. Frequency improved by $39 \%$ and nocturia by $55 \%$; average improvement for both was $47 \%$. $\delta$ Fabricius study did not use IPSS; $^{b}$ the Fabricius 1993 study reported decreases in frequency and nocturia of 39\%, and 58\%, respectively. Nocturia $\leq 1$ in $16 \%$ pre-LSESr vs. $79 \%$ at end of study $(n=153)$. $v$ Redecker data evaluated nocturia before and after LSESr. $\Theta$ Ziegler did not use IPSS; he reported symptoms based on \% improvement involving weak stream, hesitancy, incomplete emptying, frequency, and nocturia. $\gamma$ Bauer only indicated percentage improvement. Talso ${ }^{\circledR}$ Uno with $37 \%$ vs. $13 \%$ for placebo. † Medeiros study used a QoL scale 6 (worst) to 1 (best) rather than 6 (worst) and 0 (best). $\infty$ Aliaev 2009 is a 2-year extension of the 6-month 2007 paper. $\Delta$, mean change; -, negative change; \#, number; \%, percent change; +, positive change; $\mathrm{CO}_{2}$, carbon dioxide; IPSS, International Prostate Symptom Score; mos, months; QoL, quality of life; Qmax, peak urinary flow $(\mathrm{mL} / \mathrm{s})$; Ref., citation reference. 
The mean number of patients in the evaluable non-English-language studies for LSESr for efficacy in LUTS was 460, influenced by the Vahlensieck 1993 study with 1334 patients [16], the Derakhshani 1997 study with 1047 patients at the study end [19] and the Eickenberg 1997 study with 6967 patients [20]. The mean study duration across the 27 evaluable non-English-language papers was 12 months, influenced by Aliaev 2002 (60 months) [26], Breza 2005 (12 months) [33], Aliaev 2009 (24 months) [30], Vinarov 2010 (36 months) [31], and especially Aliaev 2013 (120 months) [32]. The contributions of nonEnglish peer-reviewed articles were invaluable to gain a broader perspective on Serenoa repens vs. LUTS. For five decades, the noted American news broadcaster Paul Harvey would conclude each episode with "The rest of the story." Our scientific research should do just that (i.e., review the full scope of the literature and tell the full story).

\section{LSESr Has a High Safety Profile in Contrast to Counterpart Prescription Drugs}

In the extensive review of peer-reviewed literature on LSESr, a safety profile of high tolerability and low side effects has been a consistent finding. A collection of 50 articles focused on the safety and tolerability of LSESr, with eight having study durations ranging from two to fifteen years [26,30,32,34-38]. Safety and tolerability of LSESr were never issues of concern per the Cochrane reviews, multiple meta-analyses, and the EMA monograph. Despite these sources questioning the therapeutic value of LSESr, they all concurred that LSESr was associated with minimal side effects and a highly acceptable safety profile [39-46]. The Cochrane 2012 meta-analysis, for example, reported that adverse effects associated with LSESr were not statistically significant [44]. In the STEP trial, there was no evidence of toxicity compared with placebo using escalating daily doses of LSESr (carbon dioxide extraction) up to $960 \mathrm{mg}$ per day; this included the risk of serious adverse events or non-serious symptomatic adverse events [47]. Of additional relevance is that the long-term studies ( 2 to 15 years duration) cited earlier have used all three major extraction processes, specifically, hexane, ethanol, and carbon dioxide, and no significant side effects were reported.

The two-year study by Pytel et al. [36] reported an incidence of side effects of 5.8\% for Permixon ${ }^{\circledR}$, whereas the three-year study by Schulman et al. [48], using tamsulosin reported side effects in $26 \%$ of patients. Ye et al. evaluated LSESr in 354 patients over six months and reported side effects in $1.18 \%$ of patients, which was almost identical to the $1.89 \%$ rate in the placebo arm [49]. In the placebo-controlled CAMUS trial, there were no significant differences in the incidence of adverse events between LSESr (ethanol extraction) and placebo [50]. The adverse sexual side effects of $\alpha$-blockers and $5 \alpha$-reductase inhibitors, which include decreased libido, retrograde ejaculation, and a decrease in ejaculate volume [51], are non-issues in men using LSESr [36,37,52,53]. In a 2007 study using a $320 \mathrm{mg}$ ethanolic extract of Serenoa repens (EESr), Prostamol ${ }^{\circledR}$ Uno (Berlin Chemie), a combination of tamsulosin with Prostamol Uno was used in the first 3 months of treatment followed by ongoing treatment for another six months with half the study population receiving either the combination vs. Prostamol Uno monotherapy. At nine months, 10.6\% reported retrograde ejaculation and $11 \%$ hypotensive episodes in the combination arm vs. no side effects in the Prostamol Uno arm [54]. In the context of treating LUTS, it is apparent that the adverse effects of LSESr are negligible in contrast to the counterpart prescription drugs currently in use.

\section{An Anti-Inflammatory Effect Appears to Be the Major Mechanism of Action of LSESr}

Many proposed mechanisms of action have been postulated to explain the effects of LSESr vs. LUTS. These include anti-androgenic, anti-proliferative, anti- $\alpha 1$-adrenergic, and anti-inflammatory activity [55-58]. Each of these possible mechanisms influences urinary tract symptoms through a different pathway [56]. An in-depth critical analysis of all proposed mechanisms of action of LSESr is not addressed here, but two postulated mechanisms, $5 \alpha$-reductase inhibition and an anti-inflammatory effect are discussed further. 


\section{1. $5 \alpha$-Reductase Inhibition}

LSESr has been shown to inhibit the reduction of testosterone to dihydrotestosterone (DHT) by inhibiting the activity of the $5 \alpha$-reductase enzyme, of which there are three major isoforms (Types 1, 2 and 3) [56,59,60]. In epithelial and fibroblast cell cultures, the hexane-sterolic extract of Serenoa repens (HSESr), commercially available as Permixon (Pierre Fabre Medicament S.A., Paris, France), has demonstrated the highest inhibitory activity and lowest variability in effect among seven commercial LSESr products available in Europe [61]. Two of the long-chain fatty acids, linoleic and oleic acids account for onethird of the lipidosterolic profile and are active inhibitors of $5 \alpha$-reductase Type 1 and to a lesser extent, $5 \alpha$-reductase Type 2 . LSESr has been shown to decrease DHT predominantly in the tissue of the periurethral zone of the prostate, an area primarily responsible for urinary obstruction caused by BPH [62]. However, LSESr does not reduce serum levels of DHT, PSA, testosterone, or intra-prostatic testosterone levels [63-65]. In contrast, the two major 5-alpha reductase inhibitors finasteride (Proscar ${ }^{\circledR}$ ) and dutasteride (Avodart ${ }^{\circledR}$ ) significantly lower serum DHT levels [66,67]. It does not appear that a decrease in tissue DHT in the periurethral zone accounts for the major impact of LSESr, especially when compared to the reliable effects of Avodart and Proscar in serum DHT reduction and associated decreases in PSA and prostate gland volume.

\subsection{Anti-Inflammatory Effect}

An important etiologic factor in the development of $\mathrm{BPH}$, which typically clinically manifests as LUTS, is the finding of chronic histologic inflammation detected with prostate biopsies [68-71]. The publication by Song et al. is a landmark article that focuses on the many factors involved with LUTS, from the prostate to the lower and upper urinary tracts and various body systems [72]. Other factors such as age, hormone levels, lifestyle choices such as diet, smoking, alcohol consumption, and stress are additionally important [73-77]. Adverse lifestyle factors appear to contribute to an increase in inflammatory cells infiltrating the prostate [57,73]. The inflammatory cells cause damage to both epithelial and stromal cells, stimulating cytokine release and increasing the concentration of growth factors, such as fibroblast growth factor (FGF) [78]. These inflammatory processes within the prostate lead to a progressive increase in prostate volume. The presence of chronic prostatic inflammation is correlated with urinary tract symptoms $[5,69,79]$, and for this reason, inflammation is an area of intense research in the treatment of BPH [56].

The effect of the hexanic extract of Serenoa repens (HESr) on measures of inflammation was evaluated in two controlled studies [5,80]. In the Giulianelli 2012 open-label multicenter study, men with prostate diseases with associated inflammation showed significant improvement after six months in urinary flow rate, IPSS, and chronic prostatitis symptoms [80]. In Latil 2015 [5], men with moderate-to-severe LUTS were evaluated with biomarkers of chronic prostatic inflammation in an international, randomized, double-blind study comparing HESr at $320 \mathrm{mg} /$ day vs. tamsulosin at $0.4 \mathrm{mg} /$ day. Gene and protein expression biomarkers of inflammation were quantitated after three months of treatment. This revealed that two proteins involved in the recruitment and trafficking of inflammatory cells, monocyte chemoattractant protein-1(MCP-1), and interferon $\gamma$ inducible protein 10 were decreased with HESr but slightly raised after tamsulosin. After a comprehensive gene expression analysis, a favorable anti-inflammatory effect on gene expression was observed in $73.3 \%$ of HESr patients vs. only $26.6 \%$ in patients receiving tamsulosin. In this study, a subset of patients with overexpression of macrophage migration inhibitory factor (MIF) had an average IPSS decline of 6.4 points for HESr vs. 6.5 for tamsulosin. MIF is a T-cell inflammatory cytokine, and its expression appears to be activated by a higher inflammatory microenvironment [81].

Additional studies using histologic and immunohistochemical criteria have demonstrated that LSESr reduces prostatic inflammation $[5,57,79,82-85]$. LSESr decreases B-cell infiltrates and serum levels of key cytokines such as interleukin-1 $\beta$ (IL-1 $\beta$ ) and tumor necrosis factor- $\alpha$ (TNF- $\alpha)$ [79]. LSESr has been found to differentially affect proliferation 
and apoptosis in BPH by upregulating anti-inflammatory genes and downregulating proinflammatory genes [56]. In the process of inflammation, interleukins will upregulate androgen receptor (AR) activity and lessen the efficacy of $5 \alpha$-reductase inhibitors like finasteride or dutasteride. $5 \alpha$-reductase inhibitors decrease DHT, which is a ligand for the AR. The result is a decrease in DHT-AR binding and amelioration of BPH. Therefore, LSESr may prove to be a valuable adjunct to $5 \alpha$-reductase inhibitors in the context of inflammation by inhibiting interleukin-stimulated up-regulation of the AR [57].

As noted previously, our study criteria excluded publications involving LSESr vs. LUTS in the context of non-bacterial prostatitis. Upon reflection, this may have been in error given the extremely high presence of histologically documented chronic inflammation in prostate biopsies of men with LUTS [42,68,70,86-90]. In fact, a brief search of the literature reveals several articles on the effectiveness of LSESr vs. chronic prostatitis/chronic pelvic pain syndrome (CP/CPPS) [91-99]. Given that LSESr lowers IL-1 $\beta$, TNF- $\alpha$, MCP-1, and other pro-inflammatory cytokines, the use of LSESr may be of paramount importance vs. other inflammatory conditions, age-related degenerative diseases, and neoplasia. In such contexts, biomarkers of inflammation are routinely abnormal and signal transduction pathway aberrancies are commonly found. In fact, peer-reviewed studies indicate cancer cell death resulting from the downregulation of tumor-associated growth factors such as IL-6 [100,101], COX-2 [102,103], akt [103,104], LTB4 [103], STAT 3 [105,106], urokinase-type plasminogen activator [107], basic fibroblast growth factor (bFGF, FGF- $\beta$, FGF2) [108], and proinflammatory cytokines [103] occurring with the use of Serenoa repens, and specifically LSESr. This warrants clinical investigation in light of the high therapeutic index evidenced in patients receiving LSESr in the treatment of LUTS.

\section{The Onset of LUTS Response to LSESr Occurs as Early as 4 Weeks}

In multiple publications, three months is the most commonly reported time for the onset of action of LSESr vs. LUTS, but a few studies have documented a significant response as early as six weeks. There is difficulty in knowing the earliest time to therapeutic action, because patients are typically not followed at close intervals, such as every two weeks. A small number of studies have evaluated patients at 4-to-6-week intervals. Debruyne et al. studied a total of 811 patients with an IPSS of $>10$ in a 12-month, double-blind, randomized study with a 1-month run-in period to exclude patients non-compliant in taking placebo [109]. The study compared Permixon at $320 \mathrm{mg} /$ day with tamsulosin at $0.4 \mathrm{mg} /$ day. At 6 weeks, the IPSS for Permixon dropped approximately 4.7 points, and for tamsulosin 5.2 points, with a further drop at 3 months by 0.7 and 0.8 points for Permixon and tamsulosin, respectively. This decrease was maintained for the 12-month duration of the study, with Permixon showing a total IPSS decrease of -5.9 points vs. a tamsulosin drop of 6.0 points. In the Derakhshani et al. 1997 study of 1047 patients from 357 practices, Prosta-Urgenin Uno, an EESr, was given at a dose of $320 \mathrm{mg} /$ day for 3 months [19]. At baseline, $15 \%$ of patients reported no nocturia, but after 6 weeks, the percentage of patients without nocturia increased to $38 \%$ and was absent in $54 \%$ at 3 months. Forty-seven percent of patients had three episodes of nocturia per night at baseline, but after 3 months of Prosta-Urgenin Uno, this was reduced to $10 \%$. The changes in the IPSS, QoL, and Qmax from baseline to 3 months were: $-7.4(40.4 \%),-1.61(45.9 \%)$, and $+3.7 \mathrm{~mL} / \mathrm{s}(30.8 \%)$, respectively. Specifically, for Qmax, $16 \%$ of patients went from a baseline of $12.0 \mathrm{~mL} / \mathrm{s}$ to above $18 \mathrm{~mL} / \mathrm{s}$ [19]. Recall that in the Barry 2011 study [110], the use of Prosta-Urgenin Uno was no better than placebo. In the Braeckman 1994 study, 305 men were treated over 3 months with a hCESr, (Prostaserene ${ }^{\circledR}$ ), at a dose of $160 \mathrm{mg}$ bid [111]. At approximately 6 weeks (day 45), $83 \%$ of patients reported that the drug was effective, and this percentage increased to $88 \%$ after 3 months. IPSS, QoL and Qmax absolute change and percentage improvement from baseline to 3 months were: -6.6 points $(34.7 \%) ;-1.54(41.6 \%)$; and Qmax $+2.41 \mathrm{~mL} / \mathrm{s}(26.4 \%)$, respectively [111]. In one of the first studies of LSESr published in 1983, Cirillo-Marucco reported positive effects of Permixon after 2 months [6], and Dathe in 1991 presented graphs of Qmax showing improvement with Permixon starting 
as early as 6 weeks [15]. Additional publications have noted significant improvement in one or more endpoints as early as 6 weeks $[22,52,112,113]$. Of note are the findings of a placebo-controlled study by Zhang et al. in 2021 comparing a supercritical $\mathrm{CO}_{2} \mathrm{LSESr}$ at $160 \mathrm{mg}$ bid vs. placebo. The authors found a significantly greater improvement in LUTS in the LSESr arm of 148 patients compared to the placebo group of 73 patients at two weeks from the start of the study and across the entire treatment period $(p=0.0044)$ [99]. This was a study of patients with chronic prostatitis/chronic pelvic pain syndrome (CP/CPPS) and therefore not evaluable based on our study criteria. The study is mentioned for two reasons. First, it points out that the onset of action of a standardized LSESr may occur in as little as two weeks, and second, it reinforces the probability that a major mechanism of action of LSESr involves anti-inflammation. However, in the majority of studies concerning LSESr vs. LUTS, an evaluation of response was often done at 3 months and relatively few studies formally evaluated patients at earlier times.

\section{The Response to LSESr vs. LUTS Is Durable}

There are 17 peer-reviewed studies of LSESr in which patients were treated for a minimum of 12 months to a maximum of 180 months (15 years). Of these 17 studies, 7 are 12 months in duration, with the remainder having durations of 18 months (1 study), 24 months (4), 36 months (2), 60 months (1), 120 months (1), and 180 months (1). The total number of patients involved in all 17 studies was 1976 . Two studies used a hCESr [114,115], 5 studies employed a HESr $[26,35,36,116]$ and 10 studies evaluated an EESr $[27,30-32,34,37,38,110,117,118]$. The average change in IPSS, QoL, and Qmax across all studies was $-4.8,-1.6$, and $+3.0 \mathrm{~mL} / \mathrm{s}$, respectively. Of the two hCESr studies, the averages for IPSS, QoL, and Qmax were $-5.5,-1.5$, and $+1.5 \mathrm{~mL} / \mathrm{s}$, respectively $[114,115]$. Of the five HESr studies, the averages for IPSS, QoL, and Qmax were $-5.5,-1.1$, and $+2.0 \mathrm{~mL} / \mathrm{s}$, respectively $[35,109,116]$. Of the $10 \mathrm{EESr}$ studies, the averages were $-4.1,-2.0$ and $+3.8 \mathrm{~mL} / \mathrm{s}$, respectively $[27,30-32,34,37,38,110,117,118]$. Note that of the two carbon dioxide extraction studies that lasted more than 12 months, one was the negative study by Bent [114], and, in the 10 ethanol extraction studies, one was the negative study by Barry [110]. The data extracted from these long-term studies are shown in Table 2. The data from these 17 studies using LSESr for one year or longer show that one extraction process had no apparent benefit over another. The total number of studies summarized in Table 2 did not allow for an appropriate statistical analysis.

Table 2. Long-term ( $\geq 12$ months) studies using LSESr. Seventeen studies of $\geq 12$ months involving all extraction technologies $\left(\mathrm{CO}_{2}\right.$, ethanol, hexane) with calculated average values across all studies. Nine studies of $\geq 2$ years show the first author in bolded font. The two negative studies by Bent 2006 and Barry 2001 are shaded in green.

\begin{tabular}{|c|c|c|c|c|c|c|c|c|c|c|c|}
\hline \multirow{2}{*}{$\begin{array}{l}\text { Senior } \\
\text { Author }\end{array}$} & \multirow{2}{*}{$\begin{array}{l}\text { Ref. } \\
\text { (\#) }\end{array}$} & \multirow{2}{*}{ Year } & \multirow[b]{2}{*}{ Extraction } & \multirow{2}{*}{$\begin{array}{c}\text { Serenoa Patients } \\
(\#)^{a}\end{array}$} & \multirow{2}{*}{$\begin{array}{c}\text { Study } \\
\text { Duration (mos) }\end{array}$} & \multicolumn{2}{|c|}{ IPSS * } & \multicolumn{2}{|c|}{ QoL } & \multicolumn{2}{|c|}{ Qmax } \\
\hline & & & & & & $\Delta$ & $\%$ & $\Delta$ & $\%$ & $\Delta$ & $\%$ \\
\hline Bent & [114] & 2006 & $\mathrm{CO}_{2}$ & 102 & 12 & -0.7 & 4 & & & +0.4 & 4 \\
\hline $\begin{array}{l}\text { Braeckman } \\
\pi\end{array}$ & [115] & 1997 & $\mathrm{CO}_{2}$ & 67 & 12 & -10.2 & 60 & -1.5 & 42 & +2.6 & 24 \\
\hline Aliaev $\Omega$ & [30] & 2009 & Ethanol & 50 & 24 & -4.2 & 37 & -2.2 & 52 & +2.7 & 21 \\
\hline Aliaev & [32] & 2013 & Ethanol & 38 & 120 & -1.3 & 12 & -1.1 & 35 & +3.3 & 26 \\
\hline Bach & [34] & 1996 & Ethanol & 315 & 36 & & 73 & & & +6.1 & 46 \\
\hline Barry $\pi$ & [110] & 2011 & Ethanol & 151 & 18 & -2.2 & 15 & & & & \\
\hline Breza & [27] & 2005 & Ethanol & 596 & 12 & -5.9 & 36 & -1.7 & 54 & +2.3 & 19 \\
\hline Romics & [117] & 1993 & Ethanol & 31 & 12 & & & & & +4.3 & 39 \\
\hline Saidi & [118] & 2019 & Ethanol & 40 & 12 & -2.1 & 18 & & & +0.8 & 6 \\
\hline Sinescu & [37] & 2011 & Ethanol & 120 & 24 & -5.5 & 40 & -1.8 & 50 & +5.6 & 54 \\
\hline Vinarov & [31] & 2010 & Ethanol & 50 & 36 & -6.0 & 50 & -2.0 & 50 & +4.5 & 39 \\
\hline
\end{tabular}


Table 2. Cont.

\begin{tabular}{|c|c|c|c|c|c|c|c|c|c|c|c|}
\hline \multirow{2}{*}{$\begin{array}{l}\text { Senior } \\
\text { Author }\end{array}$} & \multirow{2}{*}{$\begin{array}{l}\text { Ref. } \\
\text { (\#) }\end{array}$} & \multirow{2}{*}{ Year } & \multirow{2}{*}{ Extraction } & \multirow{2}{*}{$\begin{array}{c}\text { Serenoa Patients } \\
(\#)^{a}\end{array}$} & \multirow{2}{*}{$\begin{array}{c}\text { Study } \\
\text { Duration (mos) }\end{array}$} & \multicolumn{2}{|c|}{ IPSS * } & \multicolumn{2}{|c|}{ QoL } & \multicolumn{2}{|c|}{ Qmax } \\
\hline & & & & & & $\Delta$ & $\%$ & $\Delta$ & $\%$ & $\Delta$ & $\%$ \\
\hline Vinarov & [38] & 2019 & Ethanol & 30 & 180 & -6.0 & 50 & -3.0 & 60 & +5.0 & 45 \\
\hline Aliaev & [26] & 2002 & Hexane & 26 & 60 & -8.8 & 76 & -1.3 & 53 & +4.1 & 35 \\
\hline Debruyne & [109] & 2002 & Hexane & 350 & 12 & -4.4 & 28 & & & +1.9 & 17 \\
\hline Debruyne & [116] & 2004 & Hexane & 124 & 12 & -7.8 & 35 & -1.2 & 29 & +1.2 & 11 \\
\hline Djavan $\delta$ & [35] & 2005 & Hexane & 88 & 24 & -1.0 & 17 & -0.4 & 19 & +1.8 & 15 \\
\hline Pytel & [36] & 2002 & Hexane & 116 & 24 & -5.3 & 42 & -1.3 & 40 & +1.2 & 10 \\
\hline $\begin{array}{l}\text { Averages } \\
15 \text { positive } \\
2 \text { negative }\end{array}$ & $\begin{array}{l}7 \text { Stud } \\
\text { Idies } \\
\text { dies }\end{array}$ & & $\begin{array}{l}\text { Ethanol (10) } \\
\text { Hexane (5) } \\
\mathrm{CO}_{2}(2)\end{array}$ & 135 & 37 & -4.8 & 37 & -1.6 & 44 & $\begin{array}{c}+ \\
3.0\end{array}$ & 26 \\
\hline
\end{tabular}

${ }^{a}$ number of patients at study end, or as reported. * values for IPSS, QoL, and Qmax rounded off to one decimal point; percentages rounded off to nearest whole number. $\pi$ placebo-controlled and double-blinded, randomized study. $\Omega$ 2-year extension of the 6-month Aliaev 2007 study. $\delta$ Permixon vs. watchful waiting. $\Delta$, mean change; - , negative change; \#, number; \%, percent change; + , positive change; $\mathrm{CO}_{2}$, carbon dioxide; IPSS, International Prostate Symptom Score; mos, months; n.s., not significant; QoL, quality of life; Qmax, peak urinary flow $(\mathrm{mL} / \mathrm{s})$; Ref, reference citation.

\section{The Early Use of LSESr Delays the Progression of LUTS/BPH}

In the evolution of $\mathrm{BPH}$, an increase in LUTS is characteristic of progressive disease. If there is indeed a significant effect of high-quality LSESr on LUTS endpoints and the safety profile of that LSESr is better than the available prescription drugs for LUTS, then early and sustained use of an LSESr could conceivably halt or delay the progression of BPH. A pro-active approach to LUTS/BPH therapy would therefore involve not only achieving relief in the patient's subjective complaints but also stopping the progression of the disease.

Studies on the natural progression of BPH have been performed and have revealed a marked deterioration of between $24 \%$ and $58 \%$ in the clinical status of symptomatic BPH patients over a period of 2.4 to 5 years, as reported by Ball, Birkhoff, and Craigen [119-121]. In Bach's 3-year LSESr study involving 315 patients, the deterioration rate in LUTS symptomatology was only $13.6 \%$ and the need for surgical intervention occurred in $9.4 \%$ of patients [34]. Bach interpreted such data as a possible expression of pharmacodynamic action and that LSESr had influenced the pathogenetic or pathophysiological factors connected to BPH progression. In the Djavan 2005 study comparing watchful waiting with Permixon, 247 men were tracked over 2 years to determine if there was a difference in the progression of mild LUTS [35]. At study end, the incidence of progression was $24 \%$ in the watchful waiting group vs. $16 \%$ in men receiving Permixon $(p=0.03)$. With additional follow-up at 3 years, the rate of progression, defined as change from mild IPSS to moderate or severe IPSS or the occurrence of acute urinary retention or need for any surgical intervention, was $31 \%$ for watchful waiting vs. $19 \%$ for Permixon. At 3 years, IPSS, QoL, and Qmax had improved by $22 \%, 24 \%$, and $14 \%$, respectively, in Permixon-treated patients vs. $5 \%, 10 \%$, and $9 \%$, respectively, in the watchful waiting group (Table 3 ). This difference in progression rates between Permixon vs. watchful waiting was more pronounced in patients at high risk of progression as ascertained by a PSA of $>1.5 \mathrm{ng} / \mathrm{mL}$ and a transition zone volume of $>25$ cc per transrectal ultrasound [35]. Although the progression rates showed statistically significant differences, the degree of change in IPSS, QoL, and Qmax was disappointingly low. The differences in both absolute and percentage changes in these endpoints with LSESr are far greater in the long-term studies focused on the delay in LUTS associated BPH progression discussed below.

Emphasizing the importance of accessing the non-English-language peer-reviewed literature, the 1988 article by Orfei [13], published in Italian, concluded what other investigators confirmed 17 years later: "It is our belief that using one of the available pharmacological treatments and including Permixon, and above all starting with the appearance of the first signs of $\mathrm{BPH}$, that at least the progression of $\mathrm{BPH}$ could have been stopped, if not 
the regression of the signs of hypertrophy at a decidedly earlier stage. In such a context, the therapeutic efficacy of pharmacological treatments can be better achieved".

Table 3. Delay in the progression of LUTS/BPH with Permixon vs. Watchful Waiting (adapted from Djavan [35]. Permixon showed a statistically significant delay in progression at 2 and 3 years. Progression was defined as change from mild IPSS (1-7) to moderate (8-18) or severe IPSS (>18), or to the occurrence of surgical intervention. The "net" benefits of Permixon over Watchful Waiting were IPSS improvement of 27\%, QoL improvement of 34\%, and Qmax improvement of $23 \%$.

\begin{tabular}{|c|c|c|c|c|c|}
\hline Study Group & $\begin{array}{l}\text { Cumulative } \\
\text { Progression }\end{array}$ & $\begin{array}{c}\text { Changes * in IPSS, QoL, } \\
\text { Qmax at 2-Years }(\%)\end{array}$ & $p$ Value & $\begin{array}{l}\text { Changes ** in IPSS, } \\
\text { QoL, Qmax at 3-Years }\end{array}$ & $p$ Value \\
\hline Watchful Waiting & & \multirow{6}{*}{$\begin{array}{l}\text { IPSS: }-0.3(+5 \%) \\
\text { QoL: }-0.2(-9 \%) \\
\text { Qmax: } 0.10(-8 \%)\end{array}$} & \multirow{12}{*}{$\begin{array}{l}p=0.03 \\
\text { at 2-years }\end{array}$} & \multirow{6}{*}{$\begin{array}{l}\text { IPSS: }+5 \% \\
\text { QoL: }-10 \% \\
\text { Qmax: }-9 \%\end{array}$} & \multirow{12}{*}{$\begin{array}{l}p=0.001 \\
\text { at 3-years }\end{array}$} \\
\hline At 6 months & $6 \%$ & & & & \\
\hline At 12 months & $13 \%$ & & & & \\
\hline At 18 months & $15 \%$ & & & & \\
\hline At 24 months & $24 \%$ & & & & \\
\hline At 36 months & $31 \%$ & & & & \\
\hline Permixon & & \multirow{6}{*}{$\begin{array}{l}\text { IPSS: }-1.0(-17 \%) \\
\text { QoL: }-0.4(-19 \%) \\
\text { Qmax: }+1.8(+15 \%)\end{array}$} & & \multirow{6}{*}{$\begin{array}{l}\text { IPSS: }-22 \% \\
\text { QoL: }-24 \% \\
\text { Qmax: }+14 \%\end{array}$} & \\
\hline At 6 months & $1 \%$ & & & & \\
\hline At 12 months & $7 \%$ & & & & \\
\hline At 18 months & $9 \%$ & & & & \\
\hline At 24 months & $16 \%$ & & & & \\
\hline At 36 months & $19 \%$ & & & & \\
\hline
\end{tabular}

* Negative percentages for IPSS and QoL are improvements, while for Qmax represent deterioration. ${ }^{* *}$ No absolute values and only percentage change provided by study authors at 3 years. -, negative change; + , positive change; $\mathrm{BPH}$, benign prostatic hyperplasia; IPSS, International Prostate Symptom Score; LUTS, lower urinary tract symptoms; QoL, quality of life; Qmax, peak urinary flow (mL/s).

Major findings related to the use of an LSESr in halting or delaying the progression of LUTS are documented in multiple Russian publications led by Aliaev, Vinarov, Pytel, Sivkov, Apolikhin, Lopatkin, and others [26,30-32,36,38]. In Aliaev 2013, the safety and efficacy of Prostamol Uno in 38 men over a period of 10 years were evaluated [32]. The following issues were emphasized by Aliaev:

1. The patient's subjective evaluation of the aggravation of their condition, as determined by the IPSS, is a relevant sign of BPH progression since it helps a doctor choose the most appropriate treatment.

2. When an active supervision method is applied, the medicinal preparations are prescribed as soon as BPH symptoms start impacting the patient's quality of life. Therefore, the study of long-term pharmacological therapy of patients with minimal subjective manifestations of $\mathrm{BPH}$ and the risk of its progression is of utmost relevance.

3. Serenoa's complex pathogenetic effects are aimed at both inhibiting the process of $\mathrm{BPH}$ development and eliminating the symptoms of chronic prostatitis.

4. Because Serenoa does not decrease the PSA level it does not conceal the development of prostate cancer.

5. The presence of the risk of BPH progression was a necessary criterion for admission of patients into the observation group. The reason for this is that the presence of men not subject to the risk of $\mathrm{BPH}$ progression would have complicated our ability to prove efficacy using a multi-year continuous administration of the extract of Serenoa repens to prevent $\mathrm{BPH}$ progression.

The work of these Russian investigators and their collaboration and collegiality made it possible to analyze some publications that were impossible to translate due to the poor quality of pdf files obtained from the National Library of Medicine and the near impossibility to perform optical character recognition. The findings of these authors 
concerning the use of LSESr in preventing the progression of LUTS/BPH mandates further attention. The Vinarov 2010 study involved 100 men, of which 50 were randomized to either Prostamol Uno at $320 \mathrm{mg} /$ day and 50 to the control group [31]. Baseline eligibility requirements were an IPSS of 8 to 15 and a Qmax of $10-15 \mathrm{~mL} / \mathrm{s}$. At the end of 3 years, the changes in the Prostamol Uno group for IPSS, QoL, and Qmax were: $-6(50 \%),-2(50 \%)$, and $+4.5 \mathrm{~mL} / \mathrm{s}(39 \%)$, respectively. The control group results of $+4(36 \%),+1(25 \%)$ and $-2.6 \mathrm{~mL} / \mathrm{s}(21 \%)$ indicated deterioration in all parameters. The figures within the Vinarov 2019 publication [38], originating from data in the earlier Vinarov 2010 study [31] and presented during a workshop organized by Berlin-Chemie/Menarini at the 26th Annual EAU Congress in 2011 [122], demonstrate the changes in those endpoints (Figure 2 below).

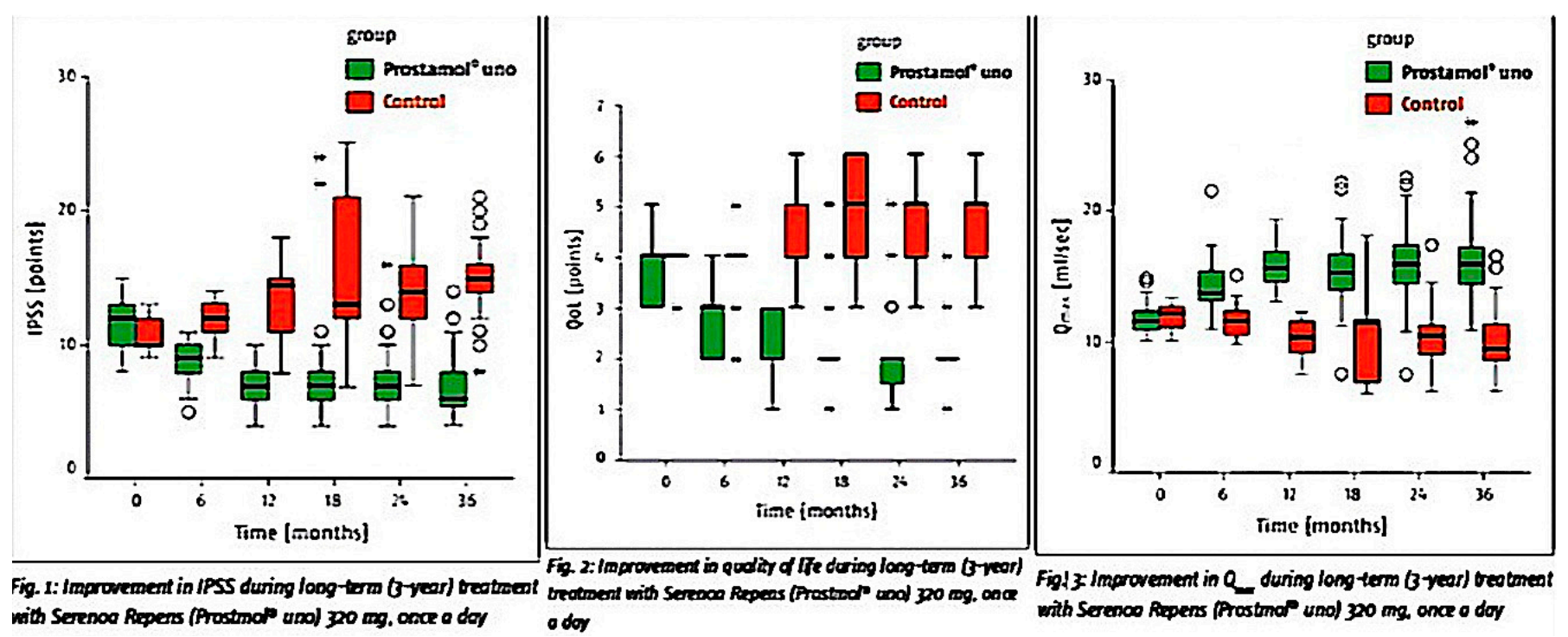

Figure 2. Changes in IPSS, QoL, and Qmax for LSESr vs. control in a 3-year intervention study. Modified after Vinarov [122].

The Vinarov 2019 study involved 30 patients with LUTS observed over 15 years [38]. These men had baseline IPSS scores of 8 to 15, symptoms for more than 3 months, and a Qmax of less than $15 \mathrm{~mL} / \mathrm{s}$. All received Prostamol Uno as a single $320 \mathrm{mg} /$ day dose. The mean baseline values for the IPSS, QoL, and Qmax were 12, 5, and 11, respectively. At the study end, the absolute changes and (percentage changes) were $-6(50 \%),-3(60 \%)$, and $+5 \mathrm{~mL} / \mathrm{s}(45 \%)$, respectively. Also, at the study end, no significant prostatic enlargement due to BPH was observed. The authors concluded that "this type of therapy can stop the progression of BPH growth and improve bladder function... " The PSA values remained stable in all patients, no patients were diagnosed with acute urinary retention, and there were no adverse effects due to LSESr [38].

\section{Conclusions}

We used stringent criteria to assess the value of Serenoa repens in the treatment of male LUTS. This involved reviewing only studies that used a lipidosterolic extract of Serenoa repens (LSESr) meeting either EMA or USP standards. At the same time, the scope of our peer-reviewed literature search included not only English-language articles but also studies of LSESr published in non-English languages and fully translated into English with data extraction that included the clinical endpoints of IPSS, QoL, and Qmax. The totality of this approach has revealed new information about LSESr vs. LUTS that indicates rapid onset of action, durability of effectiveness, and the ability of LSESr to prevent the progression of benign prostatic hyperplasia (BPH).

Funding: The author received a consulting fee for researching and compiling this review. The manuscript fees were paid by Valensa International. 
Institutional Review Board Statement: Not applicable.

Informed Consent Statement: Not applicable.

Data Availability Statement: Not applicable.

Conflicts of Interest: The author serves as a paid consultant for Valensa International. He receives a consulting fee for services to Life Extension.

Ethical Approval/Patient Consent: This is a review of the literature and did not require ethical board approval.

\section{References}

1. Alken, C.E. Leitfaden Der Urologie, 6th ed.; Thieme: Stuttgart, Germany, 1973; pp. 180-182.

2. Vahlensieck, W. Konservative behandlung von prostatadenomen. Urol. B 1972, 12, 182.

3. Vahlensieck, W. Konservative behandlung von prostatadenomen. Urol. B 1973, 13, 176.

4. Robert, G.Y. Comparison of the Effects of Hexanic extract of Serenoa repens(Permixon) and tamsulosin on inflammatory biomarkers in the treatment of benign prostatic hyperplasia-related lower urinary tract symptoms. Eur. Urol. Suppl. 2015, 14, e1470-e1474. [CrossRef]

5. Latil, A.; Petrissans, M.T.; Rouquet, J.; Robert, G.; de la Taille, A. Effects of hexanic extract of Serenoa repens (Permixon(R) 160 mg) on inflammation biomarkers in the treatment of lower urinary tract symptoms related to benign prostatic hyperplasia. Prostate 2015, 75, 1857-1867. [CrossRef]

6. Cirillo-Marucco, E.; Pagliarulo, A.; Tritto, G.; Piccinno, A.; Di Rienzo, U. Serenoa repens extract (Permixon $\left.{ }^{\circledR}\right)$ in the early treatment of prostatic hypertrophy. Urol. J. 1983, 50, 1269-1277. (In Italian) [CrossRef]

7. Cukier; Ducassou; Guillou, L. Permixon versus placebo. CR Ther. Pharmacol. Clin. 1985, 4, 15-21. (In French)

8. Tosto, A.; Rovereto, B.; Paoletti, M.C.; Rizzo, M.; Nicolucci, A.; Costantini, A. Serenoa Repens extract in the treatment of functional disorders secondary to adenoma of the prostate: Considerations on 20 cases. Urol. J. 1985, 52, 536-542. (In Italian) [CrossRef]

9. Pannunzio, E.; D’Ascenzo, R.; Giardinetti, F.; Civili, P.; Persichelli, E. Serenoa Repens vs. Gestonorone Caproato in the treatment of benign prostatic hypertrophy: Randomized study. Urol. J. 1986, 53, 696-705. (In Italian) [CrossRef]

10. Pescatore, D.; Calvi, P.; Michelotti, P. Urodynamic assessment of treatment in patients with prostatic adenoma with Serenoa repens extract. Urol. J. 1986, 53, 894-897. (In Italian) [CrossRef]

11. Authie, D.; Cauquil, J. Assessment of the effectiveness of Permixon * in daily practice multicentric study. CR Ther. Pharmacol. Clin. 1987, 5, 3-13. (In French)

12. Carreras, O.J. Our experience with hexane extract from Serenoa repens in the treatment of benign prostatic hypertrophy. Arch. Esp. Urol. 1987, 40, 310-313. (In Spanish)

13. Orfei, S.; Grumelli, B.; Galetti, G. Clinical and uroflowimetric evaluation of Permixon®in geriatrics. Urol. J. 1988, 55, 373-381. (In Italian) [CrossRef]

14. Mattei, F.M.; Capone, M.; Acconcia, A. Medicamentous therapy of benign prostatic hyperplasia with an extract of the sagebrush TW Urol. Nephrol. 1990, 2, 346-350. (In German)

15. Dathe, G.; Schmid, H. Phytotherapy for benign prostatic hyperplasia (BPH) with extractum Serenoa repens (Permixon). Urol. Ausg. B 1991, 31, 223-330. (In German)

16. Vahlensieck, W., Jr.; Volp, A.; Lubos, W.; Kuntze, M. Benign prostatic hyperplasia-treatment with sabal fruit extract. A treatment study of 1,334 patients. Fortschr. Med. 1993, 111, 323-326. (In German)

17. Vahlensieck, W.; Völp, A.; Kuntze, M.; Lubos, W. Changes in micturition in patients with benign prostatic hyperplasia under sabal fruit treatment. Urol. Ausg. B 1993, 33, 380-383. (In German)

18. Fabricius, P.G.; Vahlensieck Jr., W. Therapy for benign prostatic hyperplasia: Sabal fruit extract: One dose is enough! Therapiewoche 1993, 43, 1616-1620. (In German)

19. Derakhshani, P.; Geerke, H.; Böhnert, K.J.; Engelmann, U. Influencing the international prostate symptom score during therapy with saw palmetto fruit extract with a single daily dose. Der. Urol. B 1997, 37, 384-391. (In German) [CrossRef]

20. Eickenberg, H.U. Treatment of benign prostatic hyperplasia with a lipophilic extract from saw palmetto fruits (Sita). Der. Urol. B 1997, 37, 130-133. (In German) [CrossRef]

21. Foroutan, F. Effectiveness and tolerability of Permixon in a larger patient population (592 patients) under practical conditions. J. Urol. Urogynäkol. 1997, 2, 17-21. (In German)

22. Redecker, K.D.; Funk, P. Sabal-Extrakt WS 1473 bei benigner Prostatahyperplasie. Extracta. Urol. 1998, $21,23-25$.

23. Ziegler, H.; Holscher, U. Efficacy of saw palmetto fruit special extract WS 1473 in patients with Alken stage I-II benign prostatic hyperplasia-open multicentre study. Jatros. Urol. 1998, 14, 34-43. (In German)

24. Bauer, H.W.; Casarosa, C.; Cosci, M.; Fratta, M.; Blessmann, G. Saw palmetto fruit extract for treatment of benign prostatic hyperplasia. Results of a placebo-controlled double-blind study. MMW Fortschr. Med. 1999, 141, 62. (In German) [PubMed]

25. Medeiros, A.S.; Verona, C.B.M.; Mattos, D., Jr.; Silva, E.G.; Fonseca, G.N.; Begliomini, H.; Pous, J.H.; Cury, J.; Costa, M.M.; Prado, M.J.; et al. Efficacy and tolerability of the extract of Serenoa repens in a multicentric study in patients with symptomatic benign prostatic hyperplasia. Rev. Bras. Med. 2000, 57, 321-324. (In Portuguese) 
26. Aliaev, G.; Vinarov, A.Z.; Lokshin, K.L.; Spivak, L.G. Five-year experience in treating patients with prostatic hyperplasia patients with permixone (Serenoa repens Pierre Fabre Medicament). Urology 2002, 1, 23-25. (In Russian)

27. Breza, J.; Kliment, J.; Valansky, L.; Capova, G. Prostamol uno (alcohol extract of the fruits of Serenoa repens) in the treatment of symptomatic benign prostatic hyperplasia. Lek. Obz. 2005, 54, 139-144. (In Slovakian)

28. Aliaev, Y.G.; Apolikhin, O.I.; Mazo, E.B.; Vinarov, A.Z.; Lokshin, K.L.; Medvedev, A.A.; Permyakova, O.V.; Spivak, L.G.; Shkol'nikov, M.E. First results of a clinical trial of the efficacy and safety of Prostamol®Uno in patients with the early signs of prostatic hyperplasia. Eff. Pharm. Urol 2007, 8, 11. (In Russian)

29. Razumov, S.V.; Egorov, A.A. Prostamol Uno and $\alpha$-1-blockers in combination therapy for benign prostatic hyperplasia and the transition to monotherapy with Prostamol Uno. Eff Pharm. Urol 2007, 1, 28-30. (In Russian)

30. Aliaev, G.; Apolikhin, O.I.; Mazo, E.B.; Vinarov, A.Z.; Lokshin, K.L.; Medvedev, A.A.; Permiakova, O.V.; Spivak, L.G.; Shkol'nikov, M.E. Efficacy and safety of Prostamol-UNO in the treatment of patients with initial symptoms of prostatic adenoma and risk of progression: 2 years of investigations. Urology 2009, 4, 36-40. (In Russian)

31. Vinarov, A.Z.; Aliaev Yu, G.; Apolikhin, O.I.; Mazo, E.B.; Darenkov, S.P.; Iu, D.L.; Lokshin, K.L.; Medvedev, A.A.; Permiakova, O.V.; Spivak, L.G.; et al. Results of three-year clinical study of Prostamol Uno efficacy and safety in patients with initial symptoms of prostatic adenoma and risk of its progression. Urology 2010, 6, 3-10. (In Russian)

32. Aliaev, G.; Vinarov, A.Z.; Iu, D.L.; Spivak, L.G. The results of the 10-year study of efficacy and safety of Serenoa repens extract in patients at risk of progression of benign prostatic hyperplasia. Urology 2013, 4, 32-36. (In Russian)

33. Breza, J.; Dzurny, O.; Borowka, A.; Hanus, T.; Petrik, R.; Blane, G.; Chadha-Boreham, H. Efficacy and acceptability of tadenan (Pygeum africanum extract) in the treatment of benign prostatic hyperplasia (BPH): A multicentre trial in central Europe. Curr. Med. Res. Opin. 1998, 14, 127-139. [CrossRef]

34. Bach, D.; Ebeling, L. Long-term drug treatment of benign prostatic hyperplasia - results of a prospective 3-year multicenter study using Sabal extract IDS 89. Phytomedicine 1996, 3, 105-111. (In German) [CrossRef]

35. Djavan, B.; Fong, Y.K.; Chaudry, A.; Reissigl, A.; Anagnostou, T.; Bagheri, F.; Waldert, M.; Fajkovic, H.; Marihart, S.; Harik, M.; et al . Progression delay in men with mild symptoms of bladder outlet obstruction: A comparative study of phytotherapy and watchful waiting. World J. Urol. 2005, 23, 253-256. [CrossRef]

36. Pytel, Y.A.; Vinarov, A.; Lopatkin, N.; Sivkov, A.; Gorilovsky, L.; Raynaud, J.P. Long-term clinical and biologic effects of the lipidosterolic extract of Serenoa repens in patients with symptomatic benign prostatic hyperplasia. Adv. Ther. 2002, 19, 297-306. [CrossRef]

37. Sinescu, I.; Geavlete, P.; Multescu, R.; Gangu, C.; Miclea, F.; Coman, I.; Ioiart, I.; Ambert, V.; Constantin, T.; Petrut, B.; et al. Long-term efficacy of Serenoa repens treatment in patients with mild and moderate symptomatic benign prostatic hyperplasia. Urol. Int. 2011, 86, 284-289. [CrossRef]

38. Vinarov, A.Z.; Spivak, L.G.; Platonova, D.V.; Rapoport, L.M.; Korolev, D.O. 15 years' survey of safety and efficacy of Serenoa repens extract in benign prostatic hyperplasia patients with risk of progression. Urology 2019, 86, 17-22. [CrossRef] [PubMed]

39. Descotes, J.L.; Rambeaud, J.J.; Deschaseaux, P.; Faure, G. Placebo-Controlled evaluation of the efficacy and. tolerability of Permixon®in benign prostatic hyperplasia after exclusion of placebo responders. Clin. Drug Investig. 1995, 9, 291-297. [CrossRef]

40. Laekeman, G.; Vlietinck, A. Assessment Report on Serenoa Repens (W. Bartram) Small, Fructus. Available online: http:/ www. ema.europa.eu/docs/en_GB/document_library/Herbal_-_HMPC_assessment_report/2014/12/WC500179593.pdf (accessed on 14 November 2020).

41. MacDonald, R.; Tacklind, J.W.; Rutks, I.; Wilt, T.J. Serenoa repens monotherapy for benign prostatic hyperplasia (BPH): An updated Cochrane systematic review. BJU Int. 2012, 109, 1756-1761. [CrossRef]

42. Novara, G.; Giannarini, G.; Alcaraz, A.; Cozar-Olmo, J.M.; Descazeaud, A.; Montorsi, F.; Ficarra, V. Efficacy and Safety of hexanic lipidosterolic extract of Serenoa repens (Permixon) in the treatment of lower urinary tract symptoms due to benign prostatic hyperplasia: Systematic review and meta-analysis of randomized controlled trials. Eur. Urol. Focus 2016, 2, 553-561. [CrossRef]

43. Stepanov, V.N.; Siniakova, L.A.; Sarrazin, B.; Raynaud, J.P. Efficacy and tolerability of the lipidosterolic extract of Serenoa repens (Permixon) in benign prostatic hyperplasia: A double-blind comparison of two dosage regimens. Adv. Ther. 1999, 16, 231-241. [PubMed]

44. Tacklind, J.; Macdonald, R.; Rutks, I.; Stanke, J.U.; Wilt, T.J. Serenoa repens for benign prostatic hyperplasia. Cochrane Database Syst. Rev. 2012, 12, CD001423. [CrossRef]

45. Vela-Navarrete, R.; Alcaraz, A.; Rodriguez-Antolin, A.; Minana Lopez, B.; Fernandez-Gomez, J.M.; Angulo, J.C.; Castro Diaz, D.; Romero-Otero, J.; Brenes, F.J.; Carballido, J.; et al. Efficacy and safety of a hexanic extract of Serenoa repens (Permixon((R)) ) for the treatment of lower urinary tract symptoms associated with benign prostatic hyperplasia (LUTS/BPH): Systematic review and meta-analysis of randomised controlled trials and observational studies. BJU Int. 2018, 122, 1049-1065.

46. Wilt, T.; Ishani, A.; Mac Donald, R. Serenoa repens for benign prostatic hyperplasia. Cochrane Database Syst. Rev. 2002. [CrossRef]

47. Avins, A.L.; Bent, S.; Staccone, S.; Badua, E.; Padula, A.; Goldberg, H.; Neuhaus, J.; Hudes, E.; Shinohara, K.; Kane, C. A detailed safety assessment of a saw palmetto extract. Complement Ther. Med. 2008, 16, 147-154. [CrossRef] [PubMed]

48. Schulman, C.C.; Cortvriend, J.; Jonas, U.; Lock, T.M.; Vaage, S.; Speakman, M.J. Tamsulosin: 3-year long-term efficacy and safety in patients with lower urinary tract symptoms suggestive of benign prostatic obstruction: Analysis of a European, multinational, multicenter, open-label study. European tamsulosin study group. Eur. Urol. 1999, 36, 609-620. [CrossRef] [PubMed] 
49. Ye, Z.; Huang, J.; Zhou, L.; Chen, S.; Wang, Z.; Ma, L.; Wang, D.; Wang, G.; Wang, S.; Liang, C.; et al. Efficacy and safety of Serenoa repens extract among patients with benign prostatic hyperplasia in china: A multicenter, randomized, double-blind, placebo-controlled trial. Urology 2019, 129, 172-179. [CrossRef] [PubMed]

50. Avins, A.L.; Lee, J.Y.; Meyers, C.M.; Barry, M.J.; Group, C.S. Safety and toxicity of saw palmetto in the CAMUS trial. J. Urol. 2013, 189, 1415-1420. [CrossRef]

51. Giuliano, F. Impact of medical treatments for benign prostatic hyperplasia on sexual function. BJU Int. 2006, 97 (Suppl. 2), 34-38. [CrossRef]

52. Carraro, J.C.; Raynaud, J.P.; Koch, G.; Chisholm, G.D.; Di Silverio, F.; Teillac, P.; Da Silva, F.C.; Cauquil, J.; Chopin, D.K.; Hamdy, F.C.; et al. Comparison of phytotherapy (Permixon) with finasteride in the treatment of benign prostate hyperplasia: A randomized international study of 1,098 patients. Prostate 1996, 29, 231-240. [CrossRef]

53. Zlotta, A.R.; Teillac, P.; Raynaud, J.P.; Schulman, C.C. Evaluation of male sexual function in patients with lower urinary tract symptoms (LUTS) associated with benign prostatic hyperplasia (BPH) treated with a phytotherapeutic agent (Permixon), Tamsulosin or Finasteride. Eur. Urol. 2005, 48, 269-276. [CrossRef]

54. Razumov, S.V.; Egorov, A.A. Expediency of switching from combined therapy with prostamol Uno and alpha-1-adrenoblockers to monotherapy with prostamol Uno in patients with prostatic adenoma. Urology 2007, 3, 47-50. (In Russian)

55. Buck, A.C. Is there a scientific basis for the therapeutic effects of Serenoa repens in benign prostatic hyperplasia? Mechanisms of action. J. Urol. 2004, 172, 1792-1799. [CrossRef] [PubMed]

56. de la Taille, A. Therapeutic approach: The Importance of controlling prostatic inflammation. Eur. Urol. Suppl. 2013, 12, 116-122. [CrossRef]

57. Ficarra, V.; Rossanese, M.; Zazzara, M.; Giannarini, G.; Abbinante, M.; Bartoletti, R.; Mirone, V.; Scaglione, F. The role of inflammation in lower urinary tract symptoms (LUTS) due to benign prostatic hyperplasia (BPH) and its potential impact on medical therapy. Curr. Urol. Rep. 2014, 15, 463. [CrossRef] [PubMed]

58. Habib, F.K. Serenoa repens: The Scientific basis for the treatment of benign prostatic hyperplasia. Eur. Urol. Suppl. 2009, 8 , 887-893. [CrossRef]

59. Wang, K.; Fan, D.D.; Jin, S.; Xing, N.Z.; Niu, Y.N. Differential expression of 5-alpha reductase isozymes in the prostate and its clinical implications. Asian J. Androl. 2014, 16, 274-279. [PubMed]

60. Yamana, K.; Labrie, F.; Luu-The, V. Human type 3 5alpha-reductase is expressed in peripheral tissues at higher levels than types 1 and 2 and its activity is potently inhibited by finasteride and dutasteride. Horm. Mol. Biol. Clin. Investig. 2010, 2, 293-299. [PubMed]

61. Scaglione, F.; Lucini, V.; Pannacci, M.; Dugnani, S.; Leone, C. Comparison of the potency of 10 different brands of Serenoa repens extracts. Eur. Rev. Med. Pharmacol. Sci. 2012, 16, 569-574.

62. Di Silverio, F.; Monti, S.; Sciarra, A.; Varasano, P.A.; Martini, C.; Lanzara, S.; D’Eramo, G.; Di Nicola, S.; Toscano, V. Effects of long-term treatment with Serenoa repens (Permixon) on the concentrations and regional distribution of androgens and epidermal growth factor in benign prostatic hyperplasia. Prostate 1998, 37, 77-83. [CrossRef]

63. Marks, L.S.; Hess, D.L.; Dorey, F.J.; Luz Macairan, M.; Cruz Santos, P.B.; Tyler, V.E. Tissue effects of saw palmetto and finasteride: Use of biopsy cores for in situ quantification of prostatic androgens. Urology 2001, 57, 999-1005. [CrossRef]

64. Rhodes, L.; Primka, R.L.; Berman, C.; Vergult, G.; Gabriel, M.; Pierre-Malice, M.; Gibelin, B. Comparison of finasteride (Proscar), a $5 \alpha$ reductase inhibitor, and various commercial plant extracts in vitro and in vivo $5 \alpha$ reductase inhibition. Prostate 1993, 22, 43-51. [CrossRef] [PubMed]

65. Strauch, G.; Perles, P.; Vergult, G.; Gabriel, M.; Gibelin, B.; Cummings, S.; Malbecq, W.; Malice, M.P. Comparison of finasteride (Proscar $\left.{ }^{\circledR}\right)$ and Serenoa repens (Permixon $\left.{ }^{\circledR}\right)$ in the inhibition of 5-Alpha reductase in healthy male volunteers. Eur. Urol. 1994, 26, 247-252. [CrossRef] [PubMed]

66. Ekman, P. Finasteride in the treatment of benign prostatic hypertrophy: An update. New indications for finasteride therapy. Scand. J. Urol. Nephrol. 1999, 203, 15-20. [CrossRef]

67. Stuart, J.D.; Lee, F.W.; Simpson Noel, D.; Kadwell, S.H.; Overton, L.K.; Hoffman, C.R.; Kost, T.A.; Tippin, T.K.; Yeager, R.L.; Batchelor, K.W.; et al. Pharmacokinetic parameters and mechanisms of inhibition of rat type 1 and 2 steroid 5alpha-reductases: Determinants for different in vivo activities of GI198745 and finasteride in the rat. Biochem. Pharm. 2001, 62, 933-942. [CrossRef]

68. Kim, S.H.; Jung, K.I.; Koh, J.S.; Min, K.O.; Cho, S.Y.; Kim, H.W. Lower urinary tract symptoms in benign prostatic hyperplasia patients: Orchestrated by chronic prostatic inflammation and prostatic calculi? Urol. Int. 2013, 90, 144-149. [CrossRef] [PubMed]

69. Nickel, J.C.; Roehrborn, C.G.; Castro-Santamaria, R.; Freedland, S.J.; Moreira, D.M. Chronic Prostate inflammation is associated with severity and progression of benign prostatic hyperplasia, lower urinary tract symptoms and risk of acute urinary retention. J. Urol. 2016, 196, 1493-1498. [CrossRef] [PubMed]

70. Nickel, J.C.; Roehrborn, C.G.; O'Leary, M.P.; Bostwick, D.G.; Somerville, M.C.; Rittmaster, R.S. The relationship between prostate inflammation and lower urinary tract symptoms: Examination of baseline data from the REDUCE trial. Eur. Urol. 2008, 54, 1379-1384. [CrossRef]

71. Robert, G.; Descazeaud, A.; Allory, Y.; Vacherot, F.; De La Taille, A. Should we investigate prostatic inflammation for the management of benign prostatic hyperplasia? Eur. Urol. Suppl. 2009, 8, 879-886. [CrossRef]

72. Song, Q.; Abrams, P.; Sun, Y. Beyond prostate, beyond surgery and beyond urology: The "3Bs" of managing non-neurogenic male lower urinary tract symptoms. Asian J. Urol. 2019, 6, 169-173. [CrossRef] 
73. Lee, C.L.; Kuo, H.C. Pathophysiology of benign prostate enlargement and lower urinary tract symptoms: Current concepts. Tzu-Chi Med. J. 2017, 29, 79-83.

74. Lin, P.H.; Freedland, S.J. Lifestyle and lower urinary tract symptoms: What is the correlation in men? Curr. Opin. Urol. 2015, 25, 1-5. [CrossRef]

75. Raheem, O.A.; Parsons, J.K. Associations of obesity, physical activity and diet with benign prostatic hyperplasia and lower urinary tract symptoms. Curr. Opin. Urol. 2014, 24, 10-14. [CrossRef]

76. Sanford, M.T.; Rodriguez, L.V. The role of environmental stress on lower urinary tract symptoms. Curr. Opin. Urol. 2017, 27, 268-273. [CrossRef] [PubMed]

77. Zhang, L.G.; Chen, J.; Meng, J.L.; Zhang, Y.; Liu, Y.; Zhan, C.S.; Chen, X.G.; Zhang, L.; Liang, C.Z. Effect of alcohol on chronic pelvic pain and prostatic inflammation in a mouse model of experimental autoimmune prostatitis. Prostate 2019, 79, 1439-1449. [CrossRef] [PubMed]

78. Saez, C.; Gonzalez-Baena, A.C.; Japon, M.A.; Giraldez, J.; Segura, D.I.; Rodriguez-Vallejo, J.M.; Gonzalez-Esteban, J.; Miranda, G.; Torrubia, F. Expression of basic fibroblast growth factor and its receptors FGFR1 and FGFR2 in human benign prostatic hyperplasia treated with finasteride. Prostate 1999, 40, 83-88. [CrossRef]

79. Vela Navarrete, R.; Garcia Cardoso, J.V.; Barat, A.; Manzarbeitia, F.; López Farré, A. BPH and inflammation: Pharmacological Effects of permixon on histological and molecular inflammatory markers. Results of a double blind pilot clinical assay. Eur. Urol. 2003, 44, 549-555. [CrossRef]

80. Giulianelli, R.; Pecoraro, S.; Sepe, G.; Leonardi, R.; Gentile, B.C.; Albanesi, L.; Brunori, S.; Mavilla, L.; Pisanti, F.; Giannella, R.; et al. Multicentre study on the efficacy and tolerability of an extract of Serenoa repens in patients with chronic benign prostate conditions associated with inflammation. Arch. Ital. Urol. Androl. 2012, 84, 94-98. (In Italian) [PubMed]

81. Bucala, R. MIF rediscovered: Cytokine, pituitary hormone and glucocorticoid-induced regulator of the immune response. FASEB J. 1996, 10, 1607-1613. [CrossRef] [PubMed]

82. Bernichtein, S.; Pigat, N.; Camparo, P.; Latil, A.; Viltard, M.; Friedlander, G.; Goffin, V. Anti-inflammatory properties of Lipidosterolic extract of Serenoa repens (Permixon(R)) in a mouse model of prostate hyperplasia. Prostate 2015, 75, 706-722. [CrossRef]

83. Gravas, S.; Samarinas, M.; Zacharouli, K.; Karatzas, A.; Tzortzis, V.; Koukoulis, G.; Melekos, M. The effect of hexanic extract of Serenoa repens on prostatic inflammation: Results from a randomized biopsy study. World J. Urol. 2019, 37, 539-544. [CrossRef]

84. Latil, A.; Libon, C.; Templier, M.; Junquero, D.; Lantoine-Adam, F.; Nguyen, T. Hexanic lipidosterolic extract of Serenoa repens inhibits the expression of two key inflammatory mediators, MCP-1/CCL2 and VCAM-1, in vitro. BJU Int. 2012, 110, E301-E307. [CrossRef] [PubMed]

85. Sirab, N.; Robert, G.; Fasolo, V.; Descazeaud, A.; Vacherot, F.; de la Taille, A.; Terry, S. Lipidosterolic extract of Serenoa repens modulates the expression of inflammation related-genes in benign prostatic hyperplasia epithelial and stromal cells. Int. J. Mol. Sci. 2013, 14, 14301-14320. [CrossRef]

86. Bartoletti, R. Chronic Inflammatory infiltrate and benign prostatic hyperplasia: What do we know? Eur. Urol. Suppl. 2013, 12, 99-102. [CrossRef]

87. De Nunzio, C.; Salonia, A.; Gacci, M.; Ficarra, V. Inflammation is a target of medical treatment for lower urinary tract symptoms associated with benign prostatic hyperplasia. World J. Urol. 2020, 38, 2771-2779. [CrossRef] [PubMed]

88. Kramer, G.; Mitteregger, D.; Marberger, M. Is benign prostatic hyperplasia (BPH) an immune inflammatory disease? Eur. Urol. 2007, 51, 1202-1216. [CrossRef]

89. Robert, G.; Descazeaud, A.; Nicolaiew, N.; Terry, S.; Sirab, N.; Vacherot, F.; Maille, P.; Allory, Y.; de la Taille, A. Inflammation in benign prostatic hyperplasia: A 282 patients' immunohistochemical analysis. Prostate 2009, 69, 1774-1780. [CrossRef]

90. Sciarra, A.; Di Silverio, F.; Salciccia, S.; Autran Gomez, A.M.; Gentilucci, A.; Gentile, V. Inflammation and chronic prostatic diseases: Evidence for a link? Eur. Urol. 2007, 52, 964-972. [CrossRef] [PubMed]

91. Aliaev Yu, G.; Vinarov, A.Z.; Demidko Iu, L.; Spivak, L.G. Treatment of chronic prostatitis in prophylaxis of prostatic adenoma. Urologiia 2012, 39-40, 42-43.

92. Aliaev Yu, G.; Vinarov, A.Z.; Lokshin, K.L.; Spivak, L.G. Efficiency and safety of prostamol-Uno in patients with chronic abacterial prostatitis. Urologiia 2006, 1, 47-50. (In Russian)

93. Aliaev Yu, G.; Vinarov, A.Z.; Lokshin, K.L.; Spivak, L.G. Extracts Serenoa repens in the treatment of prostatic adenoma and chronic abacterial prostatitis: Results of short-term (3-month courses) therapy. Urologiia 2007, 2, 80-82.

94. Lopatkin, N.A.; Apolikhin, O.I.; Sivkov, A.V.; Alyaev Yu, G.; Komiakov, B.K.; Zhuravlev, V.N.; Oshchepkov, V.N.; Vinarov, A.Z.; Bazhenov, I.V.; Medvedev, A.A.; et al. Results of a multicenter trial of Serenoa repens extract (permixon) in patients with chronic abacterial prostatitis. Urologiia 2007, 5, 3-7. (In Russian)

95. Mazo, E.B.; Dmitriev, D.G. Clinical effect of the drug "Prostamol-Uno" in patients with benign prostatic hyperplasia and chronic prostatitis. Urologiia 2001, 5, 38-41.

96. Razumov, S.V.; Medvedev, A.A.; Chirun, N.V.; Sivkov, A.V.; Oshchepkov, V.N.; Siniukhin, V.N. Role of cytokines in the diagnosis of chronic prostatitis. Urologiia 2003, 6, 25-28.

97. Seregin, S.P.; Bratchikov, O.I.; Konoplia, A.I.; Shestakov, S.G.; Dolzhenkov, S.D.; Novikov, A.V.; Shatokhin, M.N.; Kotov, A.V. Effect of prostamol-Uno on oxidative and local immune status in patients with benign prostatic hyperplasia and chronic prostatitis. Urologiia 2002, 4, 14-16. (In Russian) 
98. Wu, T.; Zhang, X.; Wu, R.; Liu, X. Effects of prostadyn sabale capsules on chronic prostatitis. Zhonghua Nan Ke Xue Natl. J. Androl. 2004, 10, 337-339.

99. Zhang, K.; Guo, R.Q.; Chen, S.W.; Chen, B.; Xue, X.B.; Chen, S.; Huang, J.; Liu, M.; Tian, Y.; Zuo, L.; et al. The efficacy and safety of Serenoa repens extract for the treatment of patients with chronic prostatitis/chronic pelvic pain syndrome: A multicenter, randomized, double-blind, placebo-controlled trial. World J. Urol. 2021. [CrossRef] [PubMed]

100. Che, Y.; Hou, S.; Kang, Z.; Lin, Q. Serenoa repens induces growth arrest and apoptosis of human multiple myeloma cells via inactivation of STAT 3 signaling. Oncol. Rep. 2009, 22, 377-383. [CrossRef] [PubMed]

101. Silvestri, I.; Cattarino, S.; Agliano, A.; Nicolazzo, C.; Scarpa, S.; Salciccia, S.; Frati, L.; Gentile, V.; Sciarra, A. Effect of Serenoa repens (Permixon $(\mathrm{R})$ ) on the expression of inflammation-related genes: Analysis in primary cell cultures of human prostate carcinoma. J Inflamm. 2013, 10, 11. [CrossRef]

102. Goldmann, W.H.; Sharma, A.L.; Currier, S.J.; Johnston, P.D.; Rana, A.; Sharma, C.P. Saw palmetto berry extract inhibits cell growth and COX-2 expression in prostatic cancer cells. Cell Biol. Int. 2001, 25, 1117-1124. [CrossRef] [PubMed]

103. Petrangeli, E.; Lenti, L.; Buchetti, B.; Chinzari, P.; Sale, P.; Salvatori, L.; Ravenna, L.; Lococo, E.; Morgante, E.; Russo, A.; et al. Lipido-sterolic extract of Serenoa repens (LSESr, Permixon) treatment affects human prostate cancer cell membrane organization. J. Cell. Physiol. 2009, 219, 69-76. [CrossRef] [PubMed]

104. Yang, Y.; Hui, L.; Yuqin, C.; Jie, L.; Shuai, H.; Tiezhu, Z.; Wei, W. Effect of saw palmetto extract on PI3K cell signaling transduction in human glioma. Exp. Ther. Med. 2014, 8, 563-566. [CrossRef]

105. Ding, H.; Shen, J.; Yang, Y.; Che, Y. Saw Palmetto extract inhibits metastasis and antiangiogenesis through STAT3 signal pathway in glioma cell. Evid. Based Complementary Altern. Med. 2015. [CrossRef]

106. Zhou, T.; Yang, Y.; Zhang, H.; Che, Y.; Wang, W.; Lv, H.; Li, J.; Wang, Y.; Hou, S. Serenoa Repens induces growth arrest, apoptosis and inactivation of STAT3 signaling in human glioma cells. Technol. Cancer. Res. Treat. 2015, 14, 729-736. [CrossRef]

107. Ishii, K.; Usui, S.; Sugimura, Y.; Yamamoto, H.; Yoshikawa, K.; Hiran, K. Extract from Serenoa repens suppresses the invasion activity of human urological cancer cells by inhibiting urokinase-type plasminogen activator. Biol. Pharm. Bull. 2001, 24, 188-190. [CrossRef] [PubMed]

108. Baron, A.; Mancini, M.; Caldwell, E.; Cabrelle, A.; Bernardi, P.; Pagano, F. Serenoa repens extract targets mitochondria and activates the intrinsic apoptotic pathway in human prostate cancer cells. BJU Int. 2009, 103, 1275-1283. [CrossRef]

109. Debruyne, F.; Koch, G.; Boyle, P.; da Silva, F.C.; Gillenwater, J.G.; Hamdy, F.C.; Perrin, P.; Teillac, P.; Vela-Navarrete, R.; Raynaud, J.P. Comparison of a phytotherapeutic agent (Permixon) with an alpha-blocker (Tamsulosin) in the treatment of benign prostatic hyperplasia: A 1-year randomized international study. Eur. Urol. 2002, 41, 497-506. [CrossRef]

110. Barry, M.J.; Meleth, S.; Lee, J.Y.; Kreder, K.J.; Avins, A.L.; Nickel, J.C.; Roehrborn, C.G.; Crawford, E.D.; Foster, H.E., Jr.; Kaplan, S.A.; et al. Effect of increasing doses of saw palmetto extract on lower urinary tract symptoms: A randomized trial. JAMA 2011, 306, 1344-1351. [CrossRef]

111. Braeckman, J. The extract of Serenoa repens in the treatment of benign prostatic hyperplasia: A multicenter open study. Curr. Ther. Res. 1994, 55, 776-785. [CrossRef]

112. Al-Shukri, S.H.; Deschaseaux, P.; Kuzmin, I.V.; Amdiy, R.R. Early urodynamic effects of the lipido-sterolic extract of Serenoa repens (Permixon(R)) in patients with lower urinary tract symptoms due to benign prostatic hyperplasia. Prostate Cancer Prostatic Dis. 2000, 3, 195-199. [CrossRef]

113. Ju, X.B.; Gu, X.J.; Zhang, Z.Y.; Wei, Z.Q.; Xu, Z.Q.; Miao, H.D.; Zhou, W.M.; Xu, R.F.; Cheng, B.; Ma, J.G.; et al. Efficacy and safety of Saw Palmetto Extract Capsules in the treatment of benign prostatic hyperplasia. Zhonghua Nan Ke Xue Natl. J. Androl. 2015, 21, 1098-1101. (In Chinese)

114. Bent, S.; Kane, C.; Shinohara, K.; Neuhaus, J.; Hudes, E.S.; Goldberg, H.; Avins, A.L. Saw palmetto for benign prostatic hyperplasia. N. Engl. J. Med. 2006, 354, 557-566. [CrossRef] [PubMed]

115. Braeckman, J.; Bruhwyler, J.; Vanderkerckhove, K.; Géczy, J. Efficacy and safety of the extract of Serenoa repens in the treatment of benign prostatic hyperplasia: Therapeutic equivalence between twice and once daily dosage forms. Phytother. Res. 1997, 11, 558-563. [CrossRef]

116. Debruyne, F.; Boyle, P.; da Silva, C.F.; Gillenwater, J.G.; Hamdy, F.C.; Perrin, P.; Teillac, P.; Vela-Navarrete, R.; Raynaud, J.P.; Schulman, C.C. Evaluation of the clinical benefit of permixon and tamsulosin in severe BPH patients-PERMAL study subset analysis. Eur. Urol. 2004, 45, 773-780. [CrossRef] [PubMed]

117. Romics, I.; Schmitz, H.; Frang, D. Experience in treating benign prostatic hypertrophy with Sabal serrulata for one year. Int. Urol. Nephrol. 1993, 25, 565-569.

118. Saidi, S.; Stavridis, S.; Stankov, O.; Dohcev, S.; Panov, S. Effects of Serenoa repens Alcohol extract on benign prostate hyperplasia. Pril Makedon Akad Nauk Umet Odd Med Nauk. 2017, 38, 123-129. [CrossRef] [PubMed]

119. Ball, A.J.; Feneley, R.C.; Abrams, P.H. The natural history of untreated "prostatism". Br. J. Urol. 1981, 53, 613-616. [CrossRef]

120. Birkhoff, J.D.; Wiederhorn, A.R.; Hamilton, M.L.; Zinsser, H.H. Natural history of benign prostatic hypertrophy and acute urinary retention. Urology 1976, 7, 48-52. [CrossRef]

121. Craigen, A.A.; Hickling, J.B.; Saunders, C.R.; Carpenter, R.G. Natural history of prostatic obstruction. A prospective survey. J. R. Coll. Gen. Pract. 1969, 18, 226-232.

122. Vinarov, A.Z. Long-term treatment of BPH symptoms with Serenoa Repens. Eur. Urol. Today 2011, 23, 9. 